\title{
Investigating the seed germination characteristics of milk thistle (Silybum marianum L.) affected by magnetic field, sodium chloride and hydro-priming
}

\begin{abstract}
In order to study the effect of the magnetic field, hydro-priming and salinity stress on the seed germination characteristics of Milk thistle (Silybum marianum L.) an experiment in factorial in the form of completely randomized design was executed. Treatments contain two levels of hydro-priming (soaking seeds in distilled water for 24hours and use the dry seed) seven levels of magnetic field treatment $(50 \mathrm{mT}$ and $100 \mathrm{mT}$ for 20,40 and 60 minutes and control treatment without magnetic field exposure). And 3 potential levels of salinity $(0,150$ and $300 \mathrm{mM} \mathrm{NaCl})$ induced from Sodium chloride $(\mathrm{NaCl})$. Results showed that the percentage of germination, the mean germination time, coefficient of germination, normal number of seedling, plumule length, radicle length, seedling length, vigor index, plumule fresh weight, radicle fresh weight and seedling fresh weight at the $5 \%$ level were significant. Hydro-priming improved the evaluated characteristics. Also according to the obtained results it was determined that increasing the concentration of $\mathrm{NaCl}$, reduced the amount and growth of these characteristics. The results of the effects of the magnetic field also suggested that these effects were different under the strength and duration of the exposure. So that the treatments $50 \mathrm{mT}$ and $100 \mathrm{mT}$ for 20 minutes, increased vigor index and seedling fresh weight by 6 and 10 percent respectively in comparison with control treatment.
\end{abstract}

Volume 2 Issue 6 - 2015

\author{
Hessamoddin Solouki,' Parviz Rezvani \\ Moghaddam,' Ghasem Kord Phiroozjaee' \\ 'Department of Agronomy, Ferdowsi University of Mashhad, Iran
}

Correspondence: Parviz Rezvani Moghaddam, Professor of Agroecology, Department of Agronomy, Faculty of Agriculture, Ferdowsi University of Mashhad, Mashhad, Iran, Tel: +98-153179085; Email rezvani@um.ac.ir

Received: September 15, 2015 | Published: October 13, 2015

Keywords: magnetic field, medicinal plant, pre-soaking, salinity stress, seedling growth

Abbreviations: GP, germination percentage; MGT, mean germination time; CG, coefficient of germination; SVI, seed vigor index; $\mathrm{mM}$, milli molar; $\mathrm{mT}$, milli tesla

\section{Introduction}

The history of agriculture begins with seed plantation, and the production of seed forms the foundation of the primary agriculture and the following civilization. Cropping of most of the plants depends on seed germination. Early growth of the crop leads to better competition with the weeds. There is a direct relation between germination in laboratory condition and growing in soil in favorable conditions of the farm among many plants.

In dry parts of the world and Iran in which the plant faces natura stresses like, salinity stress and water stress at primary stages of germination and growth, using high vigor seeds is important. Therefore, it is emphasized to test the vigor of the seeds before sowing. ${ }^{1}$ On the other hand, the mean germination time has a direct effect on the yield. This issue has been studied through investigating the methods of seed treatment like priming and salinity.

Regarding the effect of salinity on the characteristics of seed germination, the results show that the salinity treatments have significant effect on some of the characteristics such as, the percentage of germination, the speed of germination, the radicle length, the plumule length and etc. ${ }^{2-4}$ Different reports indicate that seed priming increases the percentage, speed and the uniformity of germination. ${ }^{5-7}$

Pre-soaking of seeds has also been suggested as a manner for increase of germination. ${ }^{8-10}$ Most of the studies have focused on crops and medicinal plants have received less attention. Medical plants are of economic plants of humans which store active and special biochemical substances. Using them to treat diseases is a small part of human civilization. Milk thistle (Silybum marianum L.) is one of the specific medicinal plants that the effective substance of its seeds used in production of curing medicines for liver diseases. ${ }^{11}$

The result of an experiment in relation to investigating the effects of salinity and drought stress on seed germination characteristics of Milk thistle showed that by increasing of salinity and drought stress, radicle and plumule length decreased. ${ }^{12}$

The impact of magnetic field on live systems behavior has been studied for long terms but, its impacts on plants have been studied only during recent decades. Meanwhile the mechanism of magnetic fields effect on plants is still remained unknown. ${ }^{13}$

The results of an experiment about germination stimuli and the seedling growth of tomato (Lycopersicon esculentum L.) affected by magnetic field indicated that $3 \mathrm{mT}$ magnetic field permanently and $15 \mathrm{mT}$ for 25 minutes had the least time for germination. ${ }^{14}$

The result of a research done about the impact of magnetic field on seed germination of corn (Zea mays L.) has indicated that magnetic field decreased the mean germination time of corn. It also has a positive effect on other germination characteristics of this plant. ${ }^{15}$

The studies on the impact of magnetic fields on sunflower seeds (Helianthus annuus L.), have also indicated that sunflower seeds exposed to the magnetic fields had more germination speed, seedling length and seedling dry weight in comparison with control treatment. ${ }^{16}$ 
Since medicinal plants have important role in the health system of large population of the world people. The research and the implementation of some methods for improvement of their production are of great importance. So this experiment studied the effect of hydro-priming, two different strength of magnetic field in different time of exposure and also the effect of salinity on some germination characteristics of Milk thistle seeds.

\section{Materials and methods}

In order to study the impact of magnetic field, hydro-priming and salinity stress on germination characteristics of Milk thistle seeds, a factorial experiment in a completely randomized design with four replications carried out in Physiology laboratory of Ferdowsi university of Mashhad in 2013.

The treatments included two levels of hydro-priming (soaking of seeds in distilled water for 24 hours and use of dry seed), seven levels of magnetic field treatment $(50 \mathrm{mT}$ and $100 \mathrm{mT}$ for 20,40 and 60 minutes and control treatment without magnetic field exposure) and 3 potential levels of salinity $(0,150 \& 300$ milli molar $\mathrm{NaCl})$ induced from Sodium chloride $(\mathrm{NaCl})$. So, the experiment was carried out with 42 treatments in 2013. The evaluated characteristics were: the percentage of germination, the mean germination time, coefficient germination, normal number of seedling, plumule length, radicle length, seedling length, vigor index, plumule fresh weight, radicle fresh weight and seedling fresh weight.

In order to apply the magnetic field some magnets were used (Figure 1). Each magnet had two parts which were placed in repelling mode (similar poles facing each other). The seeds were put in a clear nylon between the magnet poles with different strength and duration time. Then seeds were put in petri dishes (Each petri dish contained 25 seeds).

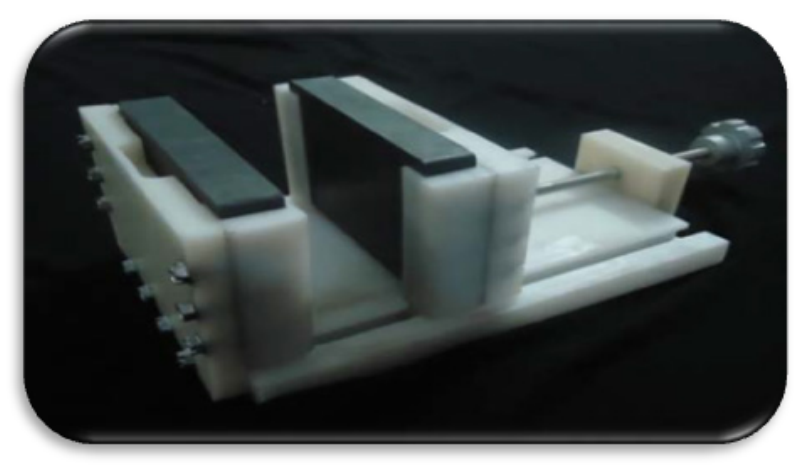

Figure I Magnetic field device.

The strength of the magnetic fields were measured via Teslameter system, Leybold- Heraeus 51652, made in Germany in Physics laboratory of Ferdowsi University of Mashhad, the faculty of basic sciences.

To create salinity stress levels, $\mathrm{NaCl}$ was used. To establish zero salinity stress, distilled water was used. Before the beginning of the experiment, all of the petri dishes were disinfected ) Sodium hypochlorite $10 \%$ solution). The sterilization of seeds was also done using Sodium hypochlorite $10 \%$ for 60 seconds. The seeds were washed 3 times after being sterilized and were put into the petri dishes. Then petri dishes were put in $25 \pm 1$ temperature. Daily counting of the germinated seeds continued for 14days. The seeds whose radicle lengths were more than 2 millimeter were counted as germinated seeds. In the last day, the number of normal seedlings was counted and characteristics were evaluated.

To estimate the Mean Germination Time (MGT), equation ${ }^{1}$ was used. ${ }^{17}$

\section{$M G T=\sum(F . X) F \sum^{1}$}

MGT, mean germination time (day); F, new number of germinated seeds per day and X: day.

In order to determine the Germination Coefficient (CG), equation ${ }^{2}$ was used. ${ }^{18}$

\section{$C G=1 M G T \times 100^{2}$}

In order to determine the seed vigor index (VI), equation ${ }^{3}$ was used $^{16}$

$\mathrm{VI}=$ Germination percentage $\times$ Seedling length (plumule length + radicle length) $)^{3}$

The data statistical analysis was performed by SAS, Version 9 and Minitab, Version 16. Means were also compared by LSD test.

\section{Results and discussion}

\section{Germination Percentage (GP)}

The results of analysis variance indicated that the impact of magnetic field, hydro-priming, salinity stress and also their interaction effects was significant on germination percentage at 1 percent probability level (Table1).

The most percentage of germination was in control treatment and $100 \mathrm{mT}$ magnetic field for 40 minutes and the least percentage of germination was observed in $50 \mathrm{mT}$ for 60 and 40 minutes respectively (Table 2).

In an experiment it was shown that the growth speed and germination of wheat (Triticum aestivum L.) and bean (Phaseolus vulgaris $\mathrm{L}$.) were increased by $7 \mathrm{mT}$ permanent magnetic field. ${ }^{19}$

The seeds were hydro-primed with distilled water had 5. 5 percent more germination than dry seeds (Table 3 ). The results of a study indicated that hydro-priming increased the seed germination percentage of cotton (Gossypium hirsutum) under drought. ${ }^{6}$

The impact of different salinity levels on germination percentage was significant (Table 1) (Table 4). The least germination percentage was observed in $300 \mathrm{mM} \mathrm{NaCl}$ and Germination percentage in $150 \mathrm{mM}$ treatment was increased in comparison with control treatment (Table 4). Besides, the germination percentage decreased in $300 \mathrm{mM}$ salinity stress in comparison with the control treatment (Table 4). The result of an experiment showed that the germination percentage of Milk thistle (Silybum marianum L.) seeds in $100 \mathrm{mM}$ salinity stress was more in comparison with other treatments. Also the treatments under salinity stress to $150 \mathrm{mM}$ level had not significantly different with control treatment but the differences were significant from $200 \mathrm{mM}$ onwards ${ }^{12}$

\section{Mean Germination Time (MGT)}

The impact of magnetic field, hydro priming, salinity stress and their interaction effects on MGT was significant (Table 1). Control treatment had the least MGT among magnetic field treatments. The most MGT was in magnetic field of $100 \mathrm{mT}$ for 60 minutes and $50 \mathrm{mT}$ 
for 20 and 60minutes (Table 2). MGT in hydro-primed seeds had significant difference with dry seeds and hydro-priming with distilled water increased the germination speed of Milk thistle seeds (Table 3).

The most amount of MGT in different levels of salinity was for $300 \mathrm{mM}$ salinity stress and then $150 \mathrm{mM}$. The least amount of MGT was also for control treatment. Salinity stress increased the germination time (Table 4). The result of an experiment showed that $250 \mathrm{mM}$ salinity decreased the germination speed of Milk thistle by 92 percent in comparison with control treatment. ${ }^{12}$ In an experiment, the application of $50 \mathrm{mT}$ magnetic field for 60 minutes had a significant effect on Fennel flower (Nigella sativa L.) germination percentage. ${ }^{13}$

In another experiment the highest speed of germination was for wheat (Triticum aestivum L.) seeds exposed in $100 \mathrm{mT}$ for 20 minutes which had 13 percent increase in comparison with control treatment. Also the germination speed in powerful magnetic field $(150 \mathrm{mT})$ was in the least amount. Thus, the powerful magnetic field had a negative impact on the seeds germination speed..$^{20}$ In a research it is reported that magnetic field decreased MGT. ${ }^{15}$

Another researcher reported that the increase of tomato (Lycopersicon esculentum L.) seeds germination percentage affected by pre-treatment of magnetic field. ${ }^{21}$ In relation to the tomato seeds reported that different strengths of the magnetic field increased the germination percentage of seeds by $8-28$ percent. ${ }^{22}$ In the regions afflicted with salinity using hydro-priming could be reduced the negative impacts of salinity on germination speed. It is reported that priming increased germination speed of cotton in salinity and temperature stresses. ${ }^{23}$

Table I Analysis of variance for evaluated characteristics of Milk thistle seeds
In relation to other plants such as sunflower (Helianthus annuus L.), Sorghum (Sorghum bicolor L.), watermelon (Citrullus lanatus), melon (Cucumis melo L.) and rice (Oryza sativa L.) it is reported that priming increased the germination speed in salinity, drought and low temperature stresses and the seedlings produced from treated seeds are stabilized more quickly. ${ }^{24-27}$

\section{Coefficient of Germination (CG)}

The impact of magnetic field, hydro-priming, salinity stress and their interaction effects was significant on germination coefficient (Table 1). The most amount of germination coefficient was related to control treatment. 50 and $100 \mathrm{mT}$ magnetic field Treatments for 60 minutes had the least amount of germination coefficient (Table 2). So the application of magnetic field for 60 minutes leads to reduction of germination coefficient of Milk thistle seeds by $12 \%$ in comparison with control treatment (Table 2).

The hydro-primed seeds with distilled water had 33 percent more germination coefficient in comparison with dry seeds. Soaking seeds with distilled water had positive effect on germination coefficient (Table 3). Different levels of salinity stress decreased germination coefficient. Salinity level of 150 and $300 \mathrm{mM}$ decreased germination coefficient by 28 and 61 percent respectively in comparison with control treatment. Increasing of salinity concentrations decreased the germination coefficient of seeds significantly (Table 4).

The results of the correlation coefficients table also indicated that the germination coefficient had a positive relation with germination percentage and negative relation with MGT (Table 5).

\begin{tabular}{|c|c|c|c|c|c|c|c|c|c|c|c|c|}
\hline S.O.V & df & $\begin{array}{l}\text { Germination } \\
\text { Percentage }\end{array}$ & $\begin{array}{l}\text { Mean } \\
\text { germination } \\
\text { time }\end{array}$ & $\begin{array}{l}\text { Germination } \\
\text { coefficient }\end{array}$ & $\begin{array}{l}\text { Number } \\
\text { of normal } \\
\text { seedling }\end{array}$ & $\begin{array}{l}\text { Plumule } \\
\text { length }\end{array}$ & $\begin{array}{l}\text { Radicle } \\
\text { length }\end{array}$ & $\begin{array}{l}\text { Seedling } \\
\text { length }\end{array}$ & $\begin{array}{l}\text { Vigor } \\
\text { index }\end{array}$ & $\begin{array}{l}\text { Plumule } \\
\text { fresh } \\
\text { weight }\end{array}$ & $\begin{array}{l}\text { Radicle } \\
\text { fresh } \\
\text { weight }\end{array}$ & $\begin{array}{l}\text { Seedling } \\
\text { fresh } \\
\text { weight }\end{array}$ \\
\hline $\begin{array}{l}\text { Hydro-priming } \\
\text { (A) }\end{array}$ & 1 & $1237 * *$ & $158 * *$ & $3761 * *$ & $65.62 * *$ & $2.58 * *$ & $26.69 * *$ & $45.83 * *$ & $517161 * *$ & $0.0025 * *$ & $0.000115^{* *}$ & $* 0.0037 * *$ \\
\hline $\begin{array}{l}\text { Magnetic field } \\
\text { (B) }\end{array}$ & 6 & $419.7 * *$ & $1.609 *$ & $30.53 * *$ & $67.94 * *$ & $0.138 * *$ & $1.785^{* *}$ & $2.456^{* *}$ & $42461 * *$ & $0.0008 * *$ & $0.000004 *$ & $0.0009 * *$ \\
\hline Salinity (C) & 2 & $108210^{* *}$ & $397.1 * *$ & $6013 * *$ & $4299.72 * *$ & $90.46^{* *}$ & $119.1 * *$ & $413.13 * *$ & $2946871 *$ & $* 0.4037 * *$ & $0.002895 * *$ & $* 0.4748 * *$ \\
\hline $\mathrm{A} \times \mathrm{B}$ & 6 & $230.2 * *$ & $1.928 * *$ & $53.68 * *$ & $40.28 * *$ & $0.262 * *$ & $4.053 * *$ & $6.302 * *$ & $55939 * *$ & $0.0011 * *$ & $0.000037^{* *}$ & $* 0.0014 * *$ \\
\hline $\mathrm{A} \times \mathrm{C}$ & 2 & $435.7 * *$ & $5 * *$ & $297.02 * *$ & $18.37 * *$ & $1.187 * *$ & $8.896 * *$ & $16.43^{* *}$ & $214827 * *$ & $0.0007^{*}$ & $0.000039 * *$ & $* 0.0011 * *$ \\
\hline $\mathrm{B} \times \mathrm{C}$ & 12 & $210.9 * *$ & $1.461 * *$ & $23.57 * *$ & $23.46 * *$ & $0.103 * *$ & $1.313 * *$ & $1.790 * *$ & $23312 * *$ & $0.0004^{*}$ & $0.000007^{* *}$ & $* 0.0004 * *$ \\
\hline$A \times B \times C$ & 12 & $119.2 * *$ & $0.957 \mathrm{~ns}$ & $20.25 * *$ & $33.42 * *$ & $0.263^{* *}$ & $2.178 * *$ & $3.792 * *$ & $35945^{* *}$ & $0.0012 * *$ & $0.000021 * *$ & $* 0.0015 \mathrm{~ns}$ \\
\hline Error & 126 & 38.2 & 0.562 & 8.46 & 3.03 & 0.03 & 0.14 & 0.229 & 2504 & 0.0002 & 0.000001 & 0.0002 \\
\hline C.V. $(\%)$ & - & 10.61 & 14.07 & 12.48 & 19.34 & 13.01 & 23.31 & 17.66 & 21.79 & 14.07 & 12.54 & 14.03 \\
\hline
\end{tabular}

The symbols * and ** are significant at I \& 5 percent probability level, respectively and the symbol ns is non significant. 
Table 2 Effect of Magnetic field treatments on evaluated characteristics of Milk thistle seeds

\begin{tabular}{|c|c|c|c|c|c|c|c|c|c|c|c|c|}
\hline $\begin{array}{l}\text { Treatme } \\
\text { (milli }\end{array}$ & $\begin{array}{l}\text { Time } \\
\text { duration }\end{array}$ & Germination & $\begin{array}{l}\text { Mean } \\
\text { germination }\end{array}$ & Germination & $\begin{array}{l}\text { Number } \\
\text { of normal }\end{array}$ & Plumule & Radicle & Seedling & Vigor & $\begin{array}{l}\text { Plumule } \\
\text { fresh weig }\end{array}$ & $\begin{array}{l}\text { Radicle } \\
\text { tfresh weig }\end{array}$ & $\begin{array}{l}\text { Seedling } \\
\text { tfresh }\end{array}$ \\
\hline Tesla) & (minutes) & & time (day) & & seedling & & & & & & & weight (g) \\
\hline & 20 & $59.8 \mathrm{ab}$ & $5.6 \mathrm{a}$ & $23.1 \mathrm{bc}$ & $10.5 \mathrm{a}$ & $1.4 \mathrm{ab}$ & $1.8 \mathrm{a}$ & $3.2 \mathrm{a}$ & $284.2 \mathrm{a}$ & $0.094 \mathrm{bcd}$ & $0.0083 \mathrm{abc}$ & $0.1025 \mathrm{bcd}$ \\
\hline $50 \mathrm{mT}$ & 40 & $56.3 \mathrm{~b}$ & $5.1 \mathrm{c}$ & $24 \mathrm{ab}$ & $8.1 \mathrm{~b}$ & $1.3 \mathrm{~cd}$ & $1.5 \mathrm{bc}$ & $2.88 \mathrm{bcd}$ & $223.8 b$ & $0.101 \mathrm{ab}$ & $0.0088 \mathrm{a}$ & $0.1108 \mathrm{ab}$ \\
\hline & 60 & $50.7 \mathrm{c}$ & $5.6 \mathrm{a}$ & $22 \mathrm{c}$ & $6.7 \mathrm{c}$ & $1.2 \mathrm{~d}$ & $0.9 \mathrm{e}$ & $2.2 \mathrm{e}$ & $154.2 \mathrm{c}$ & $0.091 \mathrm{~d}$ & $0.0076 \mathrm{c}$ & $0.0987 \mathrm{~d}$ \\
\hline & 20 & $57.8 \mathrm{ab}$ & $5.1 b c$ & $23.1 b c$ & $8.3 b$ & $1.5 \mathrm{a}$ & $1.4 \mathrm{bc}$ & $2.8 \mathrm{bc}$ & $237.4 b$ & $0.107 \mathrm{a}$ & $0.0085 \mathrm{ab}$ & $0.1157 \mathrm{a}$ \\
\hline $100 \mathrm{mT}$ & 40 & $62.7 \mathrm{a}$ & $5.3 \mathrm{abc}$ & $23.8 \mathrm{ab}$ & $10.8 \mathrm{a}$ & $1.4 \mathrm{abc}$ & $1.2 \mathrm{~d}$ & $2.5 \mathrm{~d}$ & $228.1 b$ & $0.099 \mathrm{abc}$ & $0.0078 \mathrm{bc}$ & $0.1078 \mathrm{abc}$ \\
\hline & 60 & $57.5 \mathrm{ab}$ & $5.6 \mathrm{ab}$ & $22 \mathrm{c}$ & $8.9 \mathrm{~b}$ & $1.3 \mathrm{bcd}$ & $1.3 \mathrm{~cd}$ & $2.6 \mathrm{~cd}$ & $211.1 \mathrm{~b}$ & $0.092 \mathrm{~cd}$ & $0.0078 b c$ & $0.1005 \mathrm{~cd}$ \\
\hline Control & - & $62.8 \mathrm{a}$ & $5 c$ & $25.1 \mathrm{a}$ & $11.3 \mathrm{a}$ & $1.4 \mathrm{abc}$ & $1.6 \mathrm{~b}$ & $2.9 \mathrm{ab}$ & $268.5 \mathrm{a}$ & $0.097 \mathrm{bcd}$ & $0.0082 \mathrm{abc}$ & $0.1055 \mathrm{bcd}$ \\
\hline LSD & - & 3.56 & 0.43 & 1.66 & 0.99 & 0.1 & 0.21 & 0.27 & 28.63 & 0.008 & 0.0008 & 0.008 \\
\hline
\end{tabular}

Means of each column by similar letters are not significantly different (LSD test at the $5 \%$ probability level).

Table 3 Effect of Hydro-priming on evaluated characteristics of Milk thistle seeds

\begin{tabular}{|c|c|c|c|c|c|c|c|c|c|c|c|}
\hline Treatments & $\begin{array}{l}\text { Germination } \\
\text { Percentage }\end{array}$ & $\begin{array}{l}\text { Mean } \\
\text { Germination } \\
\text { Time (day) }\end{array}$ & $\begin{array}{l}\text { Germination } \\
\text { Coefficient }\end{array}$ & $\begin{array}{l}\text { Number } \\
\text { of Normal } \\
\text { Seedling }\end{array}$ & $\begin{array}{l}\text { Plumule } \\
\text { length }(\mathrm{cm})\end{array}$ & $\begin{array}{l}\text { Radicle } \\
\text { ) length }(\mathrm{cm})\end{array}$ & $\begin{array}{l}\text { Seedling } \\
\text { length }(\mathrm{cm})\end{array}$ & $\begin{array}{l}\text { Vigor } \\
\text { Index }\end{array}$ & $\begin{array}{l}\text { Plumule } \\
\text { Fresh Weigh } \\
\text { (g) }\end{array}$ & $\begin{array}{l}\text { Radicle Fresh } \\
\text { tWeight (g) }\end{array}$ & $\begin{array}{l}\text { Seedling } \\
\text { Fresh } \\
\text { Weight (g) }\end{array}$ \\
\hline Dry seeds & $55.5 b$ & $6.3 a$ & $18.6 b$ & $8.6 \mathrm{~b}$ & $1.2 \mathrm{~b}$ & $1 b$ & $2.2 \mathrm{~b}$ & $174.1 \mathrm{~b}$ & $0.1 \mathrm{~b}$ & $0.007 \mathrm{~b}$ & $0.101 \mathrm{~b}$ \\
\hline $\begin{array}{l}\text { Hydro- } \\
\text { primed seeds }\end{array}$ & s $61 \mathrm{a}$ & $4.4 \mathrm{~b}$ & $28 \mathrm{a}$ & $9.9 \mathrm{a}$ & $1.5 \mathrm{a}$ & $1.8 \mathrm{a}$ & $3.2 \mathrm{a}$ & $285.1 \mathrm{a}$ & $0.1 \mathrm{a}$ & $0.009 a$ & $0.111 \mathrm{a}$ \\
\hline LSD & 1.903 & 0.231 & 0.885 & 0.531 & 0.053 & 0.114 & 0.145 & 15.3 & 0.004 & 0.0004 & 0.004 \\
\hline
\end{tabular}

Means of each column by similar letters are not significantly different (LSD test at the $5 \%$ probability level).

Table 4 Effect of Salinity stress on evaluated characteristics of Milk thistle seeds

\begin{tabular}{|c|c|c|c|c|c|c|c|c|c|c|c|}
\hline $\begin{array}{l}\text { Treatments } \\
\text { (milli Molar) }\end{array}$ & $\begin{array}{l}\text { Germination } \\
\text { percentage }\end{array}$ & $\begin{array}{l}\text { Mean } \\
\text { germination } \\
\text { time (day) }\end{array}$ & $\begin{array}{l}\text { Germination } \\
\text { coefficient }\end{array}$ & $\begin{array}{l}\text { Number } \\
\text { of normal } \\
\text { seedling }\end{array}$ & $\begin{array}{l}\text { Plumule } \\
\text { length }(\mathrm{cm})\end{array}$ & $\begin{array}{l}\text { Radicle } \\
\text { length }(\mathrm{cm})\end{array}$ & $\begin{array}{l}\text { Seedling } \\
\text { length }(\mathrm{cm})\end{array}$ & $\begin{array}{l}\text { Vigor } \\
\text { index }\end{array}$ & $\begin{array}{l}\text { Plumule } \\
\text { fresh weigh } \\
\text { (g) }\end{array}$ & $\begin{array}{l}\text { Radicle } \\
\text { tfresh } \\
\text { weight (g) }\end{array}$ & $\begin{array}{l}\text { Seedling fresh } \\
\text { weight }(\mathrm{g})\end{array}$ \\
\hline $0 \mathrm{mM}$ & $82.4 b$ & $3.2 \mathrm{c}$ & $33.4 \mathrm{a}$ & $17.4 \mathrm{a}$ & $2.5 \mathrm{a}$ & $2.9 \mathrm{a}$ & $5.4 \mathrm{a}$ & $458.8 \mathrm{a}$ & $0.2 \mathrm{a}$ & $0.013 \mathrm{a}$ & $0.167 \mathrm{a}$ \\
\hline $150 \mathrm{mM}$ & $84.9 \mathrm{a}$ & $4.5 b$ & $23.8 \mathrm{~b}$ & $10.3 b$ & $1.5 \mathrm{~b}$ & $1.2 \mathrm{~b}$ & $2.7 \mathrm{~b}$ & $230 \mathrm{~b}$ & $0.1 \mathrm{~b}$ & $0.011 \mathrm{~b}$ & $0.151 b$ \\
\hline $300 \mathrm{mM}$ & $7.5 \mathrm{c}$ & $8.3 \mathrm{a}$ & $12.7 \mathrm{c}$ & $0 \mathrm{c}$ & $0 \mathrm{c}$ & $0 \mathrm{c}$ & $0 \mathrm{c}$ & $0 \mathrm{c}$ & $0 \mathrm{c}$ & $0 \mathrm{c}$ & $0 \mathrm{c}$ \\
\hline LSD & 2.33 & 0.28 & 1.08 & 0.65 & 0.07 & 0.14 & 0.18 & 18.74 & 0.01 & 0.0005 & 0.005 \\
\hline
\end{tabular}

Means of each column by similar letters are not significantly different (LSD test at the $5 \%$ probability level). 
Table 5 Correlation coefficient of evaluated characteristics of Milk thistle seeds

\begin{tabular}{|c|c|c|c|c|c|c|c|c|c|c|c|}
\hline Characteristics & $\begin{array}{l}\text { Germination } \\
\text { Percentage }\end{array}$ & $\begin{array}{l}\text { Mean } \\
\text { Germination } \\
\text { Time (day) }\end{array}$ & $\begin{array}{l}\text { Germination } \\
\text { Coefficient }\end{array}$ & $\begin{array}{l}\text { Number } \\
\text { of Normal } \\
\text { Seedling }\end{array}$ & $\begin{array}{l}\text { Plumule } \\
\text { length(cm) }\end{array}$ & $\begin{array}{l}\text { Radicle } \\
\text { length }(\mathrm{cm})\end{array}$ & $\begin{array}{l}\text { Seedling } \\
\text { length }(\mathrm{cm})\end{array}$ & $\begin{array}{l}\text { Vigor } \\
\text { Index }\end{array}$ & $\begin{array}{l}\text { Plumule } \\
\text { Fresh } \\
\text { Weight (g) }\end{array}$ & $\begin{array}{l}\text { Radicle } \\
\text { Fresh } \\
\text { Weight (g) }\end{array}$ & $\begin{array}{l}\text { Seedling } \\
\text { Fresh } \\
\text { Weight (g) }\end{array}$ \\
\hline $\begin{array}{l}\text { Germination } \\
\text { Percentage }\end{array}$ & 1 & & & & & & & & & & \\
\hline $\begin{array}{l}\text { Mean } \\
\text { Germination } \\
\text { Time }\end{array}$ & $-0.83 * *$ & 1 & & & & & & & & & \\
\hline $\begin{array}{l}\text { Germination } \\
\text { Coefficient }\end{array}$ & $0.74 * *$ & $-0.91 * *$ & 1 & & & & & & & & \\
\hline $\begin{array}{l}\text { Number } \\
\text { of Normal } \\
\text { Seedling }\end{array}$ & $0.85 * *$ & $-0.81 * *$ & $0.81 *$ & 1 & & & & & & & \\
\hline Plumule length & $0.86 * *$ & $-0.85 * *$ & $0.85 * *$ & $0.89 * *$ & 1 & & & & & & \\
\hline Seedling length & $0.77 * *$ & $-0.80 * *$ & $0.86 * *$ & $0.84 * *$ & $0.95 * *$ & $0.97 * *$ & 1 & & & & \\
\hline Vigor index & $0.77 * *$ & $-0.78 * *$ & $0.86^{* *}$ & $0.83^{* *}$ & $0.92 * *$ & $0.97 * *$ & $0.98 * *$ & 1 & & & \\
\hline $\begin{array}{l}\text { Plumule fresh } \\
\text { weight }\end{array}$ & $0.93 * *$ & $-0.83 * *$ & $0.76^{* *}$ & $0.82 * *$ & $0.92 * *$ & $0.74 * *$ & $0.84 * *$ & $0.80 * *$ & 1 & & \\
\hline $\begin{array}{l}\text { Radicle fresh } \\
\text { weight }\end{array}$ & $0.89 * *$ & $-0.83 * *$ & $0.79 * *$ & $0.80 * *$ & $0.93 * *$ & $0.84 * *$ & $0.91 * *$ & $0.88^{* *}$ & $0.95 * *$ & 1 & \\
\hline $\begin{array}{l}\text { Seedling fresh } \\
\text { weight }\end{array}$ & $0.93 * *$ & $-0.83 * *$ & $0.76^{* *}$ & $0.82 * *$ & $0.93 * *$ & $0.75 * *$ & $0.85^{* *}$ & $0.81 * *$ & $0.99 * *$ & $0.96 * *$ & 1 \\
\hline
\end{tabular}

The Symbol ** shows significant correlation between evaluated characteristics (at the I percent probability level).

\section{The number of normal seedlings}

The results showed that the impact of salinity stress, hydropriming and different treatments of magnetic field on the number of normal seedlings was significant (Tables $1-4$ ).

The table of correlation coefficients also indicated that the normal number of seedling had the highest positive significant correlation $(\mathrm{r}=0.89)$ with radicle length (Table 5).

The results of an experiment in relation to the effects of different concentrations of Calcium and the magnetic field on the bean seeds germination showed that there was a significant difference among different treatments exposed to magnetic field and control treatment (No exposure to magnetic field) regarding the germination. So that the seeds treated with distilled water and deionized which were exposed to magnetic field had the highest number of germinated seeds. ${ }^{28}$ In another research results also showed that the effects of magnetic field depends on the strength and the duration of exposure to magnetic field. ${ }^{29}$

\section{The length of the plumule, radicle and the seedling}

The results of this experiment indicated that the impact of hydropriming, salinity stress and magnetic field treatments on the length of the plumule, radicle and generally on the length of the seedling was significant (Tables 1-4). So that the plumule, radicle and the seedling length in hydro-primed seeds were more than dry seeds (Table 3 ).

In relation to the impact of salinity treatments on these evaluated characteristics it was shown that by increasing salinity the growth of these characteristics decreased. So that the highest seedling length (5 $.4 \mathrm{~cm}$ ) was related to zerom $\mathrm{M} \mathrm{NaCl}$ (Table 4).

The different treatments of the magnetic field also showed that the $100 \mathrm{mT}$ treatment for 20 minutes had the highest seedling length (1 $.5 \mathrm{~cm}$ ) in comparison with other magnetic field treatments. The $50 \mathrm{mT}$ treatment for 20 minutes increased the radicle length and finally it was indicated that this treatment had the highest seedling length $(3.2 \mathrm{~cm})$ in comparison with other magnetic field treatments (Table 2). Regarding the correlation coefficients table, the seedling length had a positive and significant correlation ( $\mathrm{r}=0.98)$ with Vigor index (Table 5).

In an experiment in relation to the impact of the magnetic field on Mung bean seeds (Vigna radiata L.) it was revealed that, there was a significant difference between different magnetic field treatments and control treatment. So that the seeds were exposed to magnetic field (20\& 60 hertz) had more radicle length in comparison with other treatments. ${ }^{30}$ In other studies on this issue the results indicated that, the magnetic field had a positive and significant effect on increasing of the plumule and radicle length. ${ }^{31,32}$

\section{Seed Vigor Index (SVI)}

The result of the data analysis showed that the seed vigor index in hydro-primed treatments was more than dry seeds (Tables 1) (Table 3 ). It is reported that hydro-priming is one of the simple ways to improve and increase the characteristics related to seed vigor index such as the radicle length and the plumule length. ${ }^{33}$ Also the impact of salinity treatments on seed vigor index was significant (Table 
4). Distilled water treatment had the highest vigor index (458.8) in comparison with 150 and $300 \mathrm{mM} \mathrm{NaCl}$ treatments and by increasing salinity this index was reduced. So that $150 \mathrm{mM}$ and $300 \mathrm{mM}$ treatment of $\mathrm{NaCl}$ had 50 and 100 percent decrease in comparison with zeromM treatment (Table 4).

Many reports exist in relation to the reduction of seedling length because of the salinity stress which affects the seed vigor index. ${ }^{34,35}$ Regarding the impact of the magnetic field on seed vigor, the results indicated that $50 \mathrm{mT}$ magnetic field treatments for 20 minutes had the most seed vigor index (284.2) in comparison with other magnetic field treatments (Table 2).

In studies conducted on the impacts of the magnetic field on combination of the elements in palm (Phoenix dactyliferalL.) it is reported that the magnetic field treatments increased the seed vigor through influencing biochemical processes and the stimulation of proteins and enzymes. ${ }^{36}$

\section{Fresh weight of the plumule, radicle and the seedling}

The plumule and radicle fresh weight were significant under the influence of different treatments of magnetic field, salinity stress and hydro-priming at the 5 percent probability level (Tables $1-4)$. The lowest and the highest plumule fresh weight was observed in $50 \mathrm{mT}$ magnetic field treatment for 60 minutes and $100 \mathrm{mT}$ magnetic field treatment for 20 minutes respectively. Also, the seedling fresh weight in $100 \mathrm{mT}$ magnetic field treatment for 20 minutes was at the highest amount $(0.116 \mathrm{~g})$ in comparison with other treatments (Table 2). The results of an experiment on the impact of different magnetic field treatments on dry weight of the wheat (Triticum aestivum $\mathrm{L}$ ) and bean (Faseolus vulgaris L.) show that the increase in the strength of the magnetic field caused more growth and biomass accumulation of the seedling. ${ }^{19}$

The results for the impact of salinity treatments on the fresh weight of the plumule and the radicle indicated that increase in salinity decreased these indices, so that increase in salinity concentration from zero to $150 \mathrm{mM}$ decreased the fresh weight of the plumule by 50 percent (Table 4).

The results of the correlation coefficients table also clearly showed that the plumule fresh weight had the most positive and significant correlation $\left(\mathrm{r}=1^{* *}\right)$ with the seedling fresh weight (Table 5).

In a study about the impacts of the magnetic field on Soybean seedling (Glaysin max) it is reported that the mean fresh weight of the seedlings that exposed to magnetic field was higher than the control treatment. ${ }^{37}$ In another study on the biological characteristics of the corn under the influence of the magnetic field, it was discovered that $0.15 \mathrm{mT}$ magnetic field for 20 minutes increased total fresh weight of the corn in comparison with the control treatment. ${ }^{38}$

\section{Conclusion}

Many experiments have studied the impact of salinity and hydropriming on different indices of seed and seedling so far, and the reports have been different about variety of plants..$^{34,39}$ Today besides these methods, it is paramount to pay attention to physical and nonchemical methods which have improved the quality of seeds. One of these methods is magnetic field. In this regard, the results of this study showed that different strengths of the magnetic field and different time durations are important factors which can influence the plant growth components. So, taking in to consideration the investigations done on this issue and despite different reports such as the increase of seed vigor index through affecting biochemical processes as well as the stimulation of proteins and enzymes activities, the effects of magnetic field on many plant species is still unknown and requires more comprehensive research.

\section{Acknowledgements}

The authors acknowledge from Dr.Hassan Feyzi and Ferdowsi University of Mashhad, Faculty of agriculture, plant physiology laboratory.

\section{Conflict of interest}

The author declares no conflict of interest.

\section{References}

1. Koocheki A, Khajeh HM. Modern Agronomy. 2nd ed. Mashhad, Iran: Jihad Daneshgahi Press; 2008. 704 p.

2. Saeedi AK, Omidbaygi R, Khorang M. Study of Fennel germination (Foeniculum vulgare) as affected by osmo-priming pretreatment at various levels of salinity stress. Agriculture Research. 2007;7(4):15-28.

3. Amirkhiz FK, Omidi H, Heshmati S, et al. The effect of accelerating procedures on seed vigor and germination characteristics of Fennel flower (Nigella sativa L.) under salinity stress. Iranian Journal of Field Crops Research. 2012;10(2):299-310

4. Sohrabi S, Ghanbari A, Mohassel RMH, et al. Effect of salinity and temperature on the characteristics of seed germination, seedling growth, sodium and water content Invasive weed wild melons (Cucumis melo). Journal of Plant Protection. 2014;27(4):452-458.

5. Abootalebian MA, Sharifzadeh F, Jahansooz MR, et al. Effect of priming on seed germination, stabilization and yield of three wheat cultivars in Iran. Iranian Journal of Field Crop Science. 2008;39(1):145-154.

6. Soltani E, Akram GF, Maemar H. The effect of priming on germination components and seedling growth of cotton seeds under drought. Journal of Agriculture Sciences and Natural Resources. 2008;14(5).

7. Shakarami B, Dianati TG, Tabari M, et al. The effect of priming treatments on salinity tolerance of Festuca arundinacea Schreb and Festuca ovina L. seeds during germination and early growth. Iranian Journal of Rangelands and Forests Plant Breeding and Genetic Research. 2011;18(2):318-328.

8. Ghaderi A, Kamkar B, Soltani A. Seed science and technology. Mashhad, Iran: Jihad Daneshgahi Press; 2008. 512 p.

9. Moradi A, Younesi O. Effects of Osmo and Hydro-priming on Seed Parameters of Grain Sorghum (Sorghum bicolor L.). Australian Journal of Basic and Applied Sciences. 2009;3(3):1696-1700.

10. Seyedi M, Hamzei J, Bourbour A, et al. Effect of hydro-priming on germination properties and seedling growth of the sunflower (Carthamus tinctorius L.) under drought stress. Journal of Agronomy Sciences. 2014;8:63-76

11. Davazdah ES, Majnoon Hosseini N. Cultivation and Production of Certain Herbs and Spices. 2nd ed. Tehran, Iran: University of Tehran Press; 2008. 300 p.

12. Yazdani BR, Rezvani MP, Khazaie HR, et al. Effects of salinity and drought stress on the seed germination characteristics of milk thistle (Silybum marianum L.). Iranian Journal of Field Crops Research. 2010;8(1):12-19. 
13. Akbar PL, Asadi SM, Ashrafi R. Effect of magnetic field on germination, growth indices and activity of some enzymes of Fennel flower (Nigella sativa L.). Plant Biology. 2012;13:29-38.

14. Feyzi H, Rezvani MP, Sahabi P, et al. Stimulation of seed germination and Tomatoes seedling growth by using magnetic field and hydro-priming. Journal of Horticultural Science. 2012;26(3):343-349.

15. Florez M, Victoria CM, Martinez E. Exposure of maize seeds to stationary magnetic fields:Effects on germination and early growth. Environmental and Experimental Botany. 2007;59(1):68-75.

16. Vashisth A, Nagarajan S. Effect on germination and early growth characteristics in sunflower (Helianthus annuus L.) seeds exposed to static magnetic field. Journal of Plant Physiology. 2010;167(2):149-156.

17. Matthews S, Khajeh HM. Length of the lag period of germination and metabolic repair explain vigor differences in seed lots of maize (Zea mays). Seed Science Technology. 2007;35(1):200-212.

18. Ellis RH, Roberts EH. The quantification of ageing and survival in orthodox seeds. Seed Science and Technology. 1981;9(2):377-409.

19. Cakmak T, Dumlupinar R, Erdal S. Acceleration of germination and early growth of wheat and bean seedlings grown under various magnetic field and osmotic conditions. Bioelectromagnetics. 2010;31(2):120-129.

20. Feyzi H, Rezvani MP, Koocheki A, et al. Effect of different intensities and duration time of the magnetic field on germination and growth of wheat seedling (Triticum aestivum L.). Journal of Agroecology. 2012;3(4):482490.

21. Moon JDC, Sook H. Acceleration of germination of tomato seed by applying AC electric and magnetic fields. Journal of Electrostatics. 2000;48(2):103-114.

22. Meiqiang Y, Minging H, Buzhou M, et al. Stimulating effects of seed treatment by magnetized plasma on tomato growth and yield. Journal Plasma Science Technology. 2005;7(6):3143-3147.

23. Toselli ME, Casenave EC. Water content and the effectiveness of hydro and osmotic priming of cotton seeds. Seed Science and Technology. 2003;31(3):727-735.

24. Demir I, Vande VHA. The effect of priming treatments on the performance of watermelon (Citrullus lanatus) seeds under temperature and osmotic stress. Seed Science and Technology. 1999;27(3):871-875.

25. Demir KM, Okçu G, Atak M, et al. Seed treatment to overcome salinity and drought stress during germination in sunflower (Helianthus annuus L.). European Journal of Agronomy. 2006;24(4):291-295.

26. Foti S, Cosentino SL, Patane C, et al. Effect of osmo conditioning upon seed germination of Sorghum (Sorghum bicolor L.) under low temperatures. Seed Science and Technology. 2002;30:521 - 533.
27. Sivritepe N, Sivritepe $\mathrm{HO}$, Eris A. The effects of $\mathrm{NaCl}$ priming on salinity tolerance in melon seedling grown under saline conditions. Scientia Holticuturae. 2003;97(3-4):229-237.

28. Sakhnini L. Influence of $\mathrm{Ca} 2+$ in biological stimulating effects of $\mathrm{AC}$ magnetic fields on germination of bean seeds. Journal of Magnetism and Magnetic Materials. 2007;310(2):1032-1034.

29. Asgharipour MR, Razavi OM. Effects of seed pretreatment by stationary magnetic fields on germination and early growth of lentil. Australian Journal of Basic and Applied Sciences. 2011;5(12):1650-1654.

30. Huang HH, Wang SR. The effects of inverter magnetic fields on early seed germination of mung beans. Bioelectromagnetics. 2008;29(8):649-657.

31. Balouchi HR, Modarres SSAM. Electromagnetic field impact on annual medics and dodder seed germination. International Agrophysics. 2009;23:111-115.

32. Aladjadjiyan A. Influence of stationary magnetic field on lentil seeds International Agrophysics. 2010;24(3):321-324.

33. Ghassemi Gk, Aliloo AA, Valizadeh M, et al. Effects of hydro and osmo-priming on seed germination and field emergence of lentil (Lens culinaris Medik.). Notulae Botanicae Horti Agrobotanici Cluj Napoca. 2008;36(1):29-33.

34. Abdollahi F, Jafari L. Effect of $\mathrm{NaCl}$ and $\mathrm{KNO} 3$ priming on seed germination of Canola (Brasica napus L.) under salinity conditions. International Journal of Agriculture:Research and Review. 2012;2(5):573-579.

35. Sedghi M, Nemati A, Esmaielpour B. Effect of seed priming on germination and seedling growth of two medicinal plants under salinity. Emirates Journal of Food and Agriculture. 2010;22(2):130-139.

36. Dhawi F, Khayri AJM, Hassan E. Static magnetic field influence on elements composition in Date palm (Phoenix dactylifera L.). Research Journal of Agriculture and Biological Sciences. 2009;5(2):161-166.

37. Atak C, Emiroghlu O, Alikamanoghlu S, et al. Stimulation of regeneration by magnetic field in soybean (Glycine $\max$ L. Merrill) tissue cultures. Journal of Cell and Molecular Biology. 2003;2:113-119.

38. Aladjadjyan A. Study of the influence of magnetic field on some biological characteristics of Zea maiz. Journal of Central European Agriculture. 2002;3(2):89-94.

39. Abbasdokht H, Edalatpishe MR, Gholami A. The effect of hydro priming and halo priming on germination and early growth stage of wheat (Triticum aestivum L.). Desert. 2011;16(1):61-68. 